\title{
La forma y la norma: narración del poder en la ciudad a través del símbolo*
}

\author{
Rafael Mauricio París Restrepo** \\ Yobenj Aucardo Chicangana-Bayona**
}

Recibido: 2015-07-15 Enviado a pares: 2015-07-20

Aprobado por pares: 2015-08-19 Aceptado: 2015-08-30

\begin{abstract}
Resumen
El siguiente artículo se constituye desde la necesidad epistemológica de reflexionar sobre la ciudad y discernir la manera como los símbolos del poder se manifiestan y se despliegan en ella. La perspectiva de este estudio se enmarca desde la estética y la metafísica de la ciudad, más que desde su urbanismo; y para esto se han relacionado referentes estéticos y semióticos, logrando perfilar una hipótesis sobre la forma simbólica de la ciudad, la cual se articula con los instrumentos económicos y políticos que ejercen el poder en la misma.
\end{abstract}

Esta investigación sobre las estéticas de la ciudad metafísica permitió identificar el origen de la idea de ciudad como forma y símbolo que deviene en dispositivo social que propicia una perpetuación del poder, influyendo la construcción del relato social. Del mismo modo esta investigación posibilitó un acercamiento al fenómeno de desdivinización de los símbolos que conforman la ciudad y la relación de estos símbolos desdivinizados en la estructuración de un relato común definido, ya no por lo político o lo religioso, sino por el consumo, la fragmentación y la preponderancia del olvido.

Finalmente, se propone la educación como un eje donde convergen lo estético y lo ético, permitiendo una posibilidad de sentido a la hora de interactuar con los símbolos de la ciudad.

Palabras clave: ciudad, símbolos, fundamentalismo, constructivismo, metafísica de la ciudad.

* $\quad$ Este artículo de reflexión se desprende del proyecto de investigación Estéticas de la Ciudad Metafísica en la Ciencia-Ficción, realizado del año 2010 al 2013, del cual también se origina la novela De la anatomía a la autonomía. Este artículo, además, forma parte del Proyecto Fortalecimiento de grupos de investigación que soportan programas de posgrado de la Universidad Nacional de Colombia. Grupo Historia, Trabajo, Sociedad y Cultura. Código Hermes 16093. 2012-2013.

** Profesor auxiliar de la Fundación Universitaria Luis Amigó. Magíster en Estética. Universidad Nacional de Colombia.

*** Profesor Titular Facultad de Ciencias Humanas y Económicas. Universidad Nacional de Colombia. Doctor en Historia. Universidade Federal Fluminense. Brasil. 


\title{
Form and Norm: Narration on Power in the City Through the Symbol
}

\begin{abstract}
This article has been written from the epistemological need for making a reflection on the city and distinguishing the way power symbols are expressed and deployed in the city. The focus of this article is made on aesthetics and metaphysics of the city rather than on its urbanism. For this purpose, different aesthetic and semiotic factors have been related in an attempt to present a hypothesis on the symbolic form of the city, which is associated to the economic and political instruments that exercise power on the city. This research about the aesthetics of the metaphysical city allowed identifying the origin of the idea of city as both form and symbol, which becomes a social instrument that promotes perpetuation of power and has influence on the construction of social narration. This research further allowed approaching the dis-divinization phenomenon of the symbols that comprise the city and the function of such dis-divinized symbols within the structuring of a defined common narration, not for political or religious factors but for consumption, fragmentation, and preponderance of oblivion. Finally, the article proposes education as a pillar on which aesthetic and ethical factors lie, allowing having sense at the time of interacting with the city symbols.
\end{abstract}

Key words: City; symbols; fundamentalism; constructivism; city metaphysics. 


\section{Introducción}

La ciudad es la obra por excelencia de la humanidad. Una obra insólita y sorprendente, colmada de contrastes, tan habitual como cambiante, propicia a múltiples panoramas, simultáneamente cósmica y caótica, marcada por orígenes y propósitos que se ocultan en el pasado y en el velo misterioso de los mitos. La ciudad en sus múltiples manifestaciones puede ser legendaria como la Atlántida, de Platón, sagrada como la ciudad de Dios, de Agustín de Hipona, prostituta como la Babilonia bíblica, siniestra como las ciudades desiertas de Las mil noches y una noche, perfecta como la utopía de Tomás Moro o la ciudad del sol de Tomaso Campanella, reflejo de ilusiones, ambiciones, triunfos y decepciones; como señala Giuseppe Zarone:

A primera vista, la gran ciudad parece casi lo otro de la humanidad, pero se descubre inmediatamente no como lo otro, sino como lo mismo, puesto casi al desnudo, devuelto como algo externo a sí mismo, con evidencia nunca antes vista, en su radical y originaria falta de suelo, de fundamento y hasta de sentido. (Zarone, G. 2010, 8).

Luego deviene en la totalidad de la metrópolis futurista, sumida en espacios líquidos donde la vida mental discurre en contraste a la vida social, metrópoli promesa de revolución e industria, progreso y bienestar, compendio de todo lo existente, monstruosa en su proliferación, orgánica y mecánica, perfecta e imperfecta, justa e injusta, hermosa y fea; la ciudad, vista como referente de referentes, puede designar la totalidad y el límite de la capacidad humana, una imagen de sí que, "inminente como el destino, produce angustia; la angustia propia del hombre de encontrarse a sí mismo ya sólo como ciudad, y como nada más que esta ciudad, no sólo "grande", sino total, la ciudad planetaria" (Zarone, G. 2010:8).

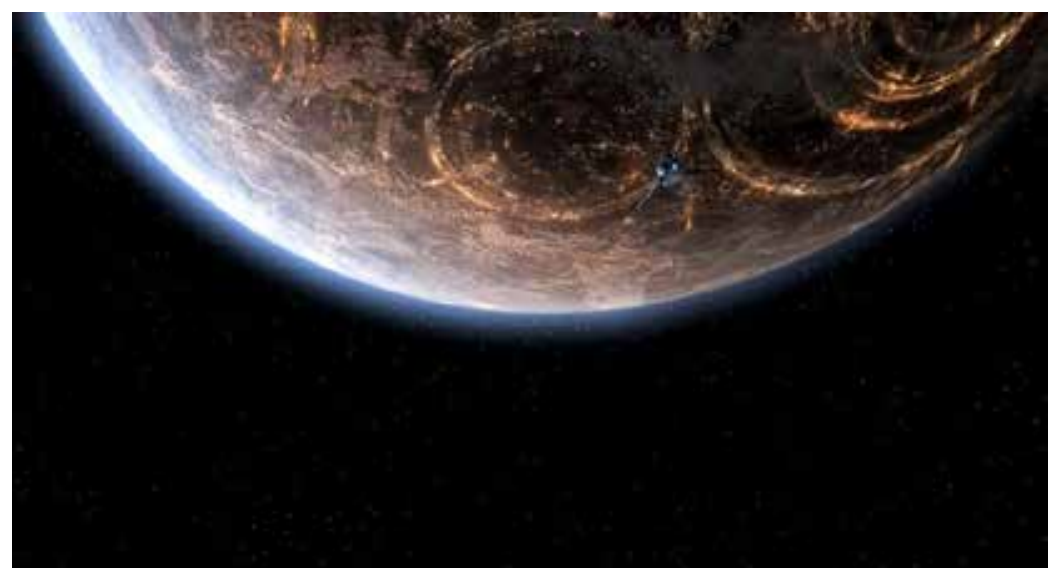

Coruscant la ciudad capital del Imperio en la saga Star Wars, una ecumenópoli que ocupaba todo el planeta. Tomado de http://quoteimg.com/coruscant-map/

La ciudad ha sido profusamente estudiada desde la arquitectura, el urbanismo, el ambientalismo, la técnica, la historia, la sociología y la antropología, preponderándose unas 
perspectivas centradas, con frecuencia, en sus aspectos físicos. Por lo tanto, este texto planteará el acercamiento a la ciudad desde dos contextos más particulares: primero, la ciudad como escenario en el cual se perpetúa la norma, y segundo, el uso de los símbolos involucrados en esa función de perpetuar la norma. Para esta reflexión se tendrán como referentes teóricos a Giuseppe Zarone con su posición sobre la metafísica de la ciudad, a René Guénon con su categorización de los símbolos sagrados y a Néstor García-Canclini con su descripción del relato de la ciudad, quienes favorecerán la configuración de una óptica específica.

\section{Fundaciones e imperios}

La ciudad empieza como el deseo de conquistar el espacio. Su fundación se emprende con una simple marca, una línea que se traza sobre un terreno, segmentando en virtud de un orden que aspira a establecerse; pero ¿quién funda ciudades?, ¿y para qué? Los poderes políticos y religiosos son los que fundan ciudades para fortalecerse, para cultivar feligreses, adeptos que crean en su orden y ayuden a propagarlo. El acto de fundar ciudades equivalía a la posesión simbólica de un territorio, la ocupación del mismo y en muchos casos, el sometimiento o expulsión de la población local (Elliot, P. 64). La elección del lugar adecuado garantizaría la permanencia y el sustento de la población, por lo tanto, la permanencia de la ciudad en el tiempo. Sebastián de Covarrubias en 1611 se refería a la ciudad en estos términos:

[...] De nombre latino civitas. De manera que ciudad es multitud de hombres ciudadanos, que se ha congregado a vivir en un mismo lugar, debajo de unas leyes y un gobierno. Ciudad se toma algunas veces por los edificios, y responde en latín urbs (Covarrubias, 1943, 427).

Desde los textos sagrados más antiguos, ya encontramos que el caos precede al orden. La creación pone fin al caos, tal y como la fundación de la ciudad conforma un nuevo cosmos. La técnica es la aliada de las instituciones políticas y religiosas y un aspecto muy importante en las experiencias de orden. Lo inconmensurable que se hace relativo y mesurable, cuando el saber técnico establece la marca que separa el cosmos del caos, tal como lo plantea Lanceros,

Determinadas y determinantes, esas experiencias de orden son el resultado de una intervención técnica; una intervención en la que la técnica todavía conserva y guarda la presencia del arte [... del espacio in-finito se hace lugar al establecer límite, valla o cercado, al talar o despejar el bosque o el matorral. El espacio continuo se ve así fracturado, cortado por discontinuidades que establecen diferencias cualitativas, niveles y jerarquías: un ámbito sagrado, por ejemplo, un espacio separado y protegido, un espacio segregado del bosque o la llanura, un espacio capturado, captado y conceptualizado (Lanceros, 2010, 12).

Una vez trazada la línea y fundada la ciudad se propaga el mito, un instrumento que relaciona la ciudad con las intenciones de las instituciones. De forma concreta el mito oculta el origen real de la ciudad, lo presenta embellecido, legendario, poético y apoteótico. 
Es a través del arte en sus múltiples manifestaciones que se reproduce incesantemente, transformando y reinventando la memoria del hecho y amoldando una historia oficial en la memoria de los ciudadanos, en la que priman héroes, magos y monstruos, que convergen para dar pertinencia al deseo de las instituciones de fundar ciudad en detrimento de los individuos normales y los grupos que son silenciados. En medio del mito, sea o no de fundación, hay una moraleja que invita a no alejarse de los fundamentos, entendidos estos como los principios establecidos desde el origen.

La Atlántida sería el referente más inmediato, un lugar entre lo real y lo imaginado, cuya sola mención evoca imágenes mentales, más o menos semejantes. Platón detalla en el diálogo titulado Critias la guerra entre Atenas y un imperio occidental, situado más allá de las columnas de Hércules, llamado Atlántida, aportando datos sobre la geografía, el origen y la organización política de ambos bandos. Si bien no hay duda acerca de Atenas, las equivalencias de Atlántida con la realidad no son claras, a pesar de los intentos por demostrar su existencia en un contexto histórico.

Al parecer la intención de Platón era, más que todo, presentar una historia de valor paradigmático, considerando cada uno de los contendientes y su simbolismo. Atenas, representando los ideales de la constitución en las épocas primigenias de su fundación, y Atlántida, las constituciones lacedemónicas o, tal vez, las del lejano Oriente. En el texto se establece que los dioses olímpicos se reparten el mundo, correspondiéndole a Poseidón, la isla de Atlántida, la cual procedió a formar:

[...] la pobló con sus descendientes, nacidos de una mujer mortal en un lugar de las siguientes características. El centro de la isla estaba ocupado por una llanura en dirección al mar, de la que se dice era la más bella de todas, y de buena calidad, y en cuyo centro, a su vez, había una montaña baja por todas partes, que distaba a unos cincuenta estadios del mar. En dicha montaña habitaba uno de los hombres que en dicha región habían nacido de la tierra, Evenor de nombre, que convivía con su mujer Leucipe. Tuvieron una única hija Clito. Cuando la muchacha alcanza la edad de tener un marido, mueren su padre y su madre. Poseidón la desea y se une a ella, y, para defender bien la colina en la que habitaba, la aísla por medio de anillos alternos de tierra y de mar, de mayor y menor dimensión: dos de tierra y tres de mar en total, cavados a partir del centro de la isla, todos a la misma distancia, por todas partes, de modo que la colina fuera inaccesible para los hombres (Platón, 2000, 285-286).

De esta manera, se explica el origen de los atlantes - descienden de Poseidón y Clito-y la formación del singular terreno, ordenado por anillos de tierra y mar; constatando, a través de los símbolos, la naturaleza dividida de los atlantes, seres de tierra y de mar, mortales y divinos. Las intenciones de Platón con este relato continúan abiertas a la interpretación, pero su insistencia en delinear un lugar, que a los ojos del historiador parece tener, en partes iguales, rasgos de la antigua Esparta o incluso de Persia, revela una posible crítica soterrada a los imperios mercantiles, señores de flotas mercantes, que culturalmente se mezclaban con quienes intercambiaban sus mercancías; así el mito de la Atlántida es una advertencia, pues es un imperio que se traga el mar, por volverse en contra de la orden de los dioses, la obligación de no perder la pureza. 
Y mientras permanecía la naturaleza divina, prosperaron todos sus bienes, (...) más cuando se agotó en ellos la parte divina porque se habían mezclado muchas veces con muchos mortales y predominó el carácter humano, ya no pudieron soportar las circunstancias que los rodearon y se pervirtieron; (...) El dios de dioses Zeus, que reina por medio de leyes, puesto que puede ver tales cosas, se dio cuenta de que una estirpe buena estaba dispuesta de manera indigna y decidió aplicarles un castigo para que se hicieran más ordenados y alcanzaran la prudencia (Platón, 2000, 295-296).

Este mito es conocido por todos, pero para los atenienses en particular, significó una metáfora de los peligros de alejarse de los fundamentos, o sea los principios reguladores de su cultura, porque fundación y fundamento siempre estarán unificados en el mito para prolongar en el tiempo el imperio fundado. Es importante no olvidar que los fundamentos o normas vienen estrictamente del cielo, por lo tanto el fundador busca que su ciudad, su espacio en la tierra, refleje la perfección del cielo.

En La Ciudad de Dios de San Agustín de Hipona, el drama de los primeros seres humanos está enlazado con la ontología de las ciudades divinas y terrenales. Afirma San Agustín: "a este (refiriéndose al género humano) lo hemos dividido en dos clases: los que viven según el hombre y los que viven según Dios. Y lo hemos designado figuradamente con el nombre de las dos ciudades (la ciudad de Dios y la ciudad del hombre), esto es, dos sociedades humanas: la una predestinada a vivir siempre con Dios; la otra a sufrir castigo eterno con el diablo" (Agustín, 1978, 576).

Esta dicotomía metafísica de la ciudad no es exclusiva de ese tiempo o lugar; en cada cultura por cada mundo del hombre, existe un mundo de Dios o de los dioses. El mundo del hombre es imperfecto, en él dominan la guerra, el hambre, el sufrimiento y la muerte, mientras que en el mundo de los dioses la plenitud espiritual o física está presente como propiedad principal. De igual modo, el mundo divino se refleja distorsionado en el mundo humano, debido a que todo lo que existe en un mundo, tiene su contraparte en el otro. Según el teólogo Emanuel Swedenborg en su libro Cielo e Infierno (1758) la flora, la fauna y las estaciones del mundo divino se reproducen de manera imperfecta en el mundo humano, siendo el hombre una parodia del ángel, pues los dioses y los ángeles no cometen las mezquindades asociadas con el hombre.

Agustín, asimismo, se refiere a la dualidad presente en las figuras de Caín y Abel: "el primer hijo nacido de los dos primeros padres del género humano fue Caín, que pertenece a la ciudad de los hombres, y el segundo, Abel, de la ciudad de Dios" (Agustín, 1978, 577). Contrapartes casi arquetípicas del virtuoso y el pecador, Caín y Abel son los personajes que enmarcan la esencia del ethos de la ciudad. Abel es el pastor, un símbolo religioso asociado con el nomadismo y la transhumancia, la humildad, el servicio y la austeridad. Los sacerdotes occidentales han valorado al pastor como paradigma del buen vivir, de la ética y la difusión de los valores, mientras que su contrario, Caín, es sedentario, el agricultor el hombre que abandona la vida nómada. Por supuesto Caín es una figura negativa, para la espiritualidad porque al abandonar su nomadismo, además, abandona la vida casi clerical 
del pastor, siendo su crimen, la metáfora de la humanidad que abandona el nomadismo para cultivar la ciudad.

Para Agustín, es también posible el tránsito de una ciudad a otra, de un estado de gracia a otro: "podemos comprobar en cada hombre lo que nos dijo el Apóstol, que no es primero lo espiritual, sino lo animal; lo espiritual viene después. Por eso cada uno, por nacer de estirpe condenada, pertenece primero, como malo y carnal, a Adán, pasando luego a ser bueno y espiritual si continúa su perfección en el renacer hacia Cristo." (Agustín, 1978, 577). Hay múltiples ejemplos de personas que ascienden a la ciudad celeste para vivir temporal o permanentemente con los dioses. En el cristianismo estaría el caso de Jesucristo y de María quienes van al cielo después de cumplir su misión en la tierra, ascendiendo en el caso de ambos, en cuerpo y alma. Igualmente Tántalo vivió entre los dioses olímpicos, pero fue castigado cuando rompió su promesa de no contar a nadie sus experiencias. Realidad y ficción, reflejo y reflejada, esta doble naturaleza de la ciudad predispone un contexto en el que lo puro y lo impuro conviven en persistente flujo.

Si no una estricta necesidad, es una vieja convención la de comparar la ciudad real —en detrimento de ella — con una imagen o modelo que presume del valor añadido de la perfección y de la trascendencia. Sea la ciudad ideal (Platón ${ }^{1}$ es, obviamente, el aludido), sea la Ciudad de Dios (San Agustín², esta vez) o la larga serie de utopías que, a lo largo de los siglos, han proyectado el pensamiento, la literatura y el arte. La ciudad real, aquella que, de diversas formas se ha ido real-izando desde sus lejanos comienzos (acaso Jericó, acaso Uruk, o Ur, o Çatal Huyuk...) hasta las actuales megalópolis tiene que justificarse; y tiene que defenderse, todavía hoy, de su pecado original. Que, según el mito bíblico, consiste en haber nacido al margen del plan y del cobijo divino, y como consecuencia del crimen ${ }^{3}$ (Lanceros, 2010, 7).

Por esta razón, la ciudad está, en esencia, maldita, por albergar los descendientes de Caín. La prole de aquel que desdeñó la austeridad del nomadismo - practicada por su hermano asesinado-, y decidió asentarse en un terreno para usufructuarse de su producción. Aún la agricultura, la minería, y la ganadería continúan impulsando la opulencia económica de la ciudad real, en detrimento de los propósitos de la ciudad celeste, donde el valor está en el patrimonio inmaterial.

Cuando la ciudad es delimitada comienza a ser llamada región, un término que intenta abarcar todas las posibles segmentaciones conceptuales del terreno. Se habla de región geográfica, económica, cultural, histórica, urbana y social. Igualmente se habla de subregiones y de ecorregiones. La precisa descripción con la cual los límites regionales

1 Platón (en griego antiguo: $\Pi \lambda \alpha \alpha \tau \omega \nu$ ) (Atenas o Egina ca. 427-347 a. C.) fue un filósofo griego seguidor de Sócratesn. y maestro de Aristóteles.

2 Agustín de Hipona o san Agustín o Aurelius Augustinus Hipponensis (Tagaste, 13 de noviembre de 354 Hippo Regius [también llamada Hipona], 28 de agosto de 430)1 es un santo, padre y doctor de la Iglesia católica.

3 Caín dijo después a su hermano Abel: "vamos al campo." Cuando se encontraron en el campo, Caín se arrojó contra su hermano Abel y lo mató. Yavé preguntó a Caín: "¿Dónde está tu hermano?”, y el respondió: "no lo sé, ¿̇oy yo, acaso, el guardián de mi hermano?". Génesis 4: 8-9. 
aparecen en los mapas contrasta con la vaguedad utilitarista con la que los Estados establecen las condiciones sobre estos límites, siendo así que la diferencia entre la paz y la guerra entre naciones, puede ser de escasos metros o de muchos kilómetros. A veces pareciera que la región fuera una lengua, una vianda o un deporte más que la división estructurada en las convenciones geográficas.

(La) Región: un territorio, acaso un país, una zona, una comarca, una extensión de terreno delimitada. Naturalmente. Pero, ¿delimitada por quién?, ¿delimitada por qué?, ¿por qué, por quién y dónde se traza la línea que de-limita, que de-fine la región?, ¿qué marca (es) la comarca?, ¿qué signo, qué crimen, qué acto de discriminación, de discernimiento o demarcación? En principio, regio no significa sólo zona o territorio delimitado, sino que alude, sobre todo en plural, a la misma línea o al límite, a la frontera que define la zona: y que zona, a su vez designa el ceñidor o la faja, el cinturón que ciñe, y así limita o demarca, lo que queda en su interior. Al pensar la región estamos, una vez más, sobre la línea. Ya no tan naturalmente (Lanceros, 2010, 5).

Siendo un ingenioso dispositivo de socialización, la ciudad es también el máximo dispositivo mnemotécnico, ya que su almacenamiento de memoria trasciende los elementos físicos creados por los habitantes, para desplegarse con vitalidad en su cultura, o sea en el núcleo de su producción, abarcando las ideas, los valores, el folclore, el arte, el diseño, la técnica y todo lo que se crea en sus confines tenues, para transmitirse en el tiempo y hacer parte de la historia.

La historia de la ciudad puede narrarse como una historia de las normas, lo que daría lugar al despliegue de una ética y de una política urbana; también puede narrarse como una historia de las formas: cuestión de percepción y estética. Creo que separar ambas historias es una operación falaz, ya que la norma se refleja en la forma, se incorpora a la forma. Y esto es lo que nos está ocupando aquí: el relato, necesariamente esquemático, de una estética de la ciudad. Pero de una estética integral, de una estética que considere los compromisos normativos y normalizadores de la forma (Lanceros, 2010, 8).

Según Patxi Lanceros, la técnica y el arte se han unido con la institución para fundar la ciudad y mantener el poder de la institución desde la imagen. Edificios gigantescos, en su sublimidad ${ }^{4}$ artística, son imágenes de poder que quedan en la memoria de los ciudadanos, muchas veces convirtiéndose en referentes que hacen reconocible su ciudad,

4 Edmund Burke (Dublín, 12 de enero de 1729 - Beaconsfield, 9 de julio de 1797), escritor y político, es considerado el padre del liberalismo-conservadurismo británico. En 1756 escribió Indagación filosófica sobre el origen de nuestras ideas acerca de lo sublime y de lo bello (A Philosophical Enquiry into the Origin of our Ideas of the Sublime and Beautiful), donde esboza unas teorías estéticas claramente neoclásicas. 
y unas ciertas tradiciones asociadas con ella. Sin embargo, estas construcciones del arte son, también, construcciones de la norma, pues a través de ellas, el poder normativo de lo político y lo religioso, literalmente lanza una sombra sobre los ciudadanos cubriéndolos, ordenándolos y poniéndolos bajo su influjo.

En un verso célebre del primer estásimo de Antígona, se refiere Sófocles a tres dominios que el hombre, que poco antes ha sido calificado como "lo más formidable"5 (to deinotaton), ha aprendido por sí mismo: el lenguaje, el pensamiento y las pasiones que ordenan ciudades (astynómous orgás ${ }^{6}$ ). Hemos de prescindir aquí, no por su menor importancia, de las dos primeras para centrarnos en la tercera. Considerando, además, que esas pasiones ordenadoras de ciudades se vierten en dos cursos de acción, obviamente relacionados, como se acaba de sugerir, desde el principio: la instauración de normas y la construcción de formas. Entre ambas, en el nudo que las ata, se produce y se reproduce la multisecular alianza o el verdadero matrimonio (no ajeno a desavenencias y conatos, nunca definitivamente consumados, de divorcio) entre la arquitectura y el poder (Lanceros, 2010, 7).

Miles de veces representada, en fotografías, ilustraciones, publicidades, merchandisings y propagandas, la ciudad fluye como imagen mentirosa, seductora, deseada, admirada, odiada y amada, mientras que su presencia, su realidad, permanece conocida solo por los pocos que quieren verla, realidad olvidada y represiva de su urbanidad, de esa huella caótica que incluye la arquitectura, la ingeniería, el arte, la flora y la fauna; pero de igual manera evidencia la basura, el abandono, la contaminación y la sobrepoblación, como componentes de su forma ecléctica. Mentirosas eran las ciudades planeadas por Hitler, Mussollini y Stalin, que ocultaban tras las vetustas estatuas, un desprecio por la vida, tan grande, como sus ambiciones. Similares en su arquitectura a estas ciudades, pero no en sus objetivos son la Nueva York y la París de principios del siglo XXI, herederas del estilo paquidérmico y grandilocuente de los arquitectos fascistas que quieren alcanzar la perfección de la utopía en la arquitectura, pero no sus valores.

5 1. En los dos primeros versos de Antígona, el texto griego usa la palabra $\tau$ o $\delta \varepsilon ı v o \tau \alpha \tau o v$ (a deinotaton) es lo que es derivado de deinos: A. inspira miedo y consiguiente asombro. El que es peligroso. B. temiendo. Sustantivo: To deinon: el miedo, el terror El término es ambivalente: es a la vez terrible y aterrador, pero también violento, que utiliza la violencia (brutal). Tomado de http://www.ac-grenoble.fr/lycee/vincent.indy/ IMG/Vocabulaire _ Antigone.doc

6 Astynómous orgás o pasiones instituyentes, el "deseo / la pasión de proporcionar leyes a las ciudades". La polis como posibilidad humana. Tomado de: https://www.u-cursos.cl/ingenieria/2010/2/EH1B2/1/ material_docente/previsualizar?id _ material $=317444$ 


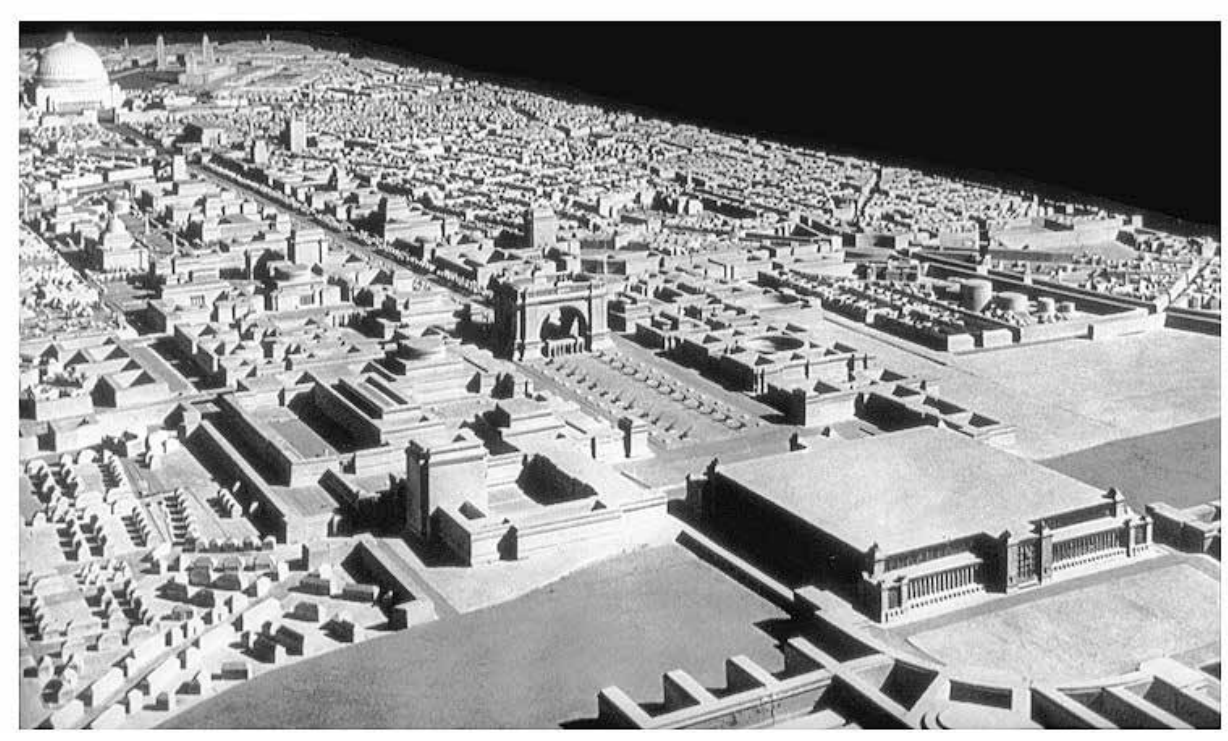

"Germania" la capital mundial imaginada por Hitler para reemplazar Berlín, fue proyectada por el arquitecto Albert Speer.

Tomado de http://www.taringa.net/posts/videos/8934772/La-superciudad-de-hitler-Germania.html

Martín Heidegger se preocupó por el auge de lo técnico, su capacidad para transformar a la humanidad en poco tiempo y la poca escrupulosidad en su aplicación:

Como la esencia de la técnica no es nada técnico, la meditación esencial sobre la técnica y la confrontación decisiva con ella tienen que acontecer en una región que, por una parte, esté emparentada con la esencia de la técnica y, por otra, no obstante, sea fundamentalmente distinta de ella. Esta región es el arte. Aunque, sin duda, sólo cuando, por su parte, la meditación sobre el arte no se cierre a la constelación de la verdad por la que nosotros preguntamos (Heidegger, M.; 1994, 37).

Heidegger señala que lo que hoy llamamos arte, en el mundo antiguo era llamado techne o técnica, y que por esta razón debemos volver a relacionar la idea de técnica con la sensibilidad, propia de las artes. Solo cuando se reconoce en la técnica una faceta sensible (la estética), es posible acercar la técnica a la ética, faceta que nunca está alejada de lo estético.

En consecuencia, una utopía vendría a ser una sociedad en la cual lo estético (lo sensible) y lo ético (las acciones), estarían atravesados en cada momento de la vida. ¿Pero qué es la utopía?, ¿un proyecto, ¿una fantasía? La utopía alude al símbolo de un mundo ideal que, contrastado con el mundo real, logra una crítica de este. La palabra fue concebida por Tomás Moro en su obra Libro del estado ideal de una república en la nueva isla de Utopía (1516), donde "Utopía" es el nombre de una isla y de la sociedad que la habita. Moro describe una comunidad imaginaria con ideas filosóficas, económicas y políticas, distintas a los 
de las comunidades de su época. La obra está estructurada en dos partes: primero hay un diálogo entre Moro y el explorador Rafael Hitlodeo, y luego viene una segunda parte en la que detalla la comunidad utópica.

Los principios éticos de Moro quedan claros cuando narra su diálogo con Hitlodeo acerca de la pertinencia de la propiedad privada y cómo los habitantes de Utopía, a diferencia de los europeos, poseen bienes comunes: "Si les hablase de aquellas cosas inventadas por Platón en su República, o de las que hacen los utópicos en la suya, aunque fuesen, como en realidad son, mejores, podrán, no obstante, parecerles extrañas por existir aquí la propiedad privada, al paso que allí todo es común" (Moro, T. 2004: 70), y prosigue: "Por otra parte amigo Moro, estimo que donde quiera que exista la propiedad privada y se mida todo por el dinero, será difícil lograr que el Estado obre justa y acertadamente, a no ser que pienses que es obrar con justicia el permitir que lo mejor vaya a parar a manos de los peores, y que se vive felizmente allí donde todo se halla repartido entre unos pocos que, mientras los demás perecen de miseria disfrutan de la mayor prosperidad" (Moro, 2004, 71).

Hitloideo describe aspectos culturales de los utópicos, en claro contraste a la Europa de Moro, marcada por la avaricia desde el descubrimiento de América. Mientras los utópicos viven en una sociedad que no ambiciona el poder, los europeos estaban separados por las rencillas entre Carlos V y Enrique VIII; mientras los utópicos viven en igualdad, los europeos estaban atravesando un momento de separación cultural, política y religiosa, que continúa hasta hoy en día; todo esto, usado por el autor para dar a entender que los utópicos son, como los europeos deberían ser. La geografía y las costumbres de Utopía son más o menos verosímiles, y es ingenioso el juego que Moro realiza con las nominaciones; la ciudad principal de Utopía se llama Amauroto (sin muros), la cual está cerca del río Anidro (sin agua) y es gobernada por un sabio llamado Ademo (sin pueblo), nominaciones adecuadas para un sitio llamado Utopía (ov́, no; тó tos, lugar = 'lo que no está en ningún lugar'), o sea, lugar inexistente.

Otra utopía fue la propuesta por Tomasso de Campanella en La Imaginaria Ciudad de Sol (1623). Esta obra está compuesta como un diálogo entre un almirante genovés y el Gran Maestre de los Hospitalarios. El marinero relata al caballero cómo se vio forzado a desembarcar en la Isla de Taprobana, donde los nativos lo conducen a la Ciudad del Sol, que está cercada por siete murallas, consagradas cada una a un astro. En la cima de una montaña se encuentra el templo dedicado al Sol. La organización política de este reino es de naturaleza teocrática; de nuevo aparece la temática de la igualdad, pues los ciudadanos reconocen que la propiedad privada es la causa del egoísmo humano y de las desavenencias entre los pueblos, y, por lo tanto, han acordado en que las pertenencias sean comunitarias.

La narración de Campanella, por momentos, es de un aserto, casi documental, como cuando describe un procedimiento que usan los guerreros para sujetar al caballo sin usar las manos: "para poder manejar con mayor soltura la clava, sujetan las riendas del caballo, no con la mano, sino con los pies. De este modo, las bridas se cruzan sobre los arzones de la silla y bajan hasta quedar sujetas a los extremos de las fíbulas. Estas 
llevan en la parte exterior una esfera de hierro, y en la parte baja un triángulo. Así, pues, al girar el pie sobre el triángulo, las esferas se ponen en movimiento, estiran las bridas y con admirable rapidez puede el caballo ser dirigido al arbitrio del jinete" (Campanella, T; 2007: 173). O cuando detalla los carros de taprobana: "emplean carros que tienen velas en la parte superior y que, gracias a un admirable engranaje, se utilizan incluso en el caso de ser adverso el viento. Cuando el viento falta, un único animal arrastra un carro grande y pesado, que al mismo tiempo resulta elegante" (Campanella, 2007, 177).

Trata de una sociedad comunista ideal en la que el poder está en manos de hombres sabios y sacerdotes. Con esto podemos ver cuán influyente fue la Iglesia sobre Tommaso Campanella. La ciudad del sol contribuyó a desarrollar la ideología progresista y a estimular el progreso social.

Moro inventa el término Utopía, aunque es justo reconocer que ya existían conceptos semejantes pues La Atlántida de Platón y la Ciudad de Dios de Agustín, ya tenían algo de esa inventiva y perfección. En el caso de Moro y Campanella, se hace aún más evidente la moraleja, pues sus historias son hábiles parodias de los diarios de viaje de Marco Polo, que critican a la nobleza europea tan aferrada a sus riquezas y tan atrasada en progreso social. En las utopías hay una invitación manifiesta a desarrollar una ideología progresista que fomente una nueva sociedad, una en la cual la libertad, la igualdad y la fraternidad estén al alcance de todos sus ciudadanos. De esta manera la perfección de las utopías no está en su desarrollo político, económico, técnico o artístico. Más bien se halla en la perfección moral de sus habitantes, su deseo de bien común y de logros que favorezcan a todas las personas, sin importan quiénes sean, creándose una imagen de ciudad que no se sustenta en la grandeza de los monumentos, sino en la percepción positiva de sus habitantes.

La estética de la representación ha dominado siempre sobre la estética de la presencia. Cierto es, si de dominio se trata. Cierto que la exhibición del poder ha dado — en todos los momentos de la historia- forma a la imagen de la ciudad; cierto que los edificios y monumentos que cobijan y exaltan los poderes se destacan en el espacio y se prolongan en el tiempo. Aquí y allá podemos admirar restos: la calzada de los muertos de Teotihuacán o las pirámides de Egipto, acrópolis, arcos de distintas fechas, de distintos triunfos, iglesias y catedrales, castillos y palacios de diferentes culturas y estilos (Lanceros, 2010, 9).

Entonces, la imagen es poder sobre el otro. Antes los arquitectos áulicos del poder construían en nombre de los reyes y del papa; hoy construyen en nombre de Time-Warner, Reuters o el Banco de América. Hacer imagen y consumirla es la obsesión de la sociedad de consumo, siendo esto lo opuesto a una experiencia estética urbana, que sea genuina. La arquitectura de lo monumental lleva en su esencia las experiencias intimidatorias, excluyentes y altivas del palacio y la catedral. Lo urbano cumple su promesa, cuando permite encuentros que no estén sesgados por la influencia de los poderosos. El orden del poder domina desde la imagen segmentando la ciudad, cultivando la región que sirve al poder y asolando las regiones que no le sirven. Pensemos en las zonas industriales de cada ciudad y en sus condiciones de lugares nocivos para el desarrollo del trabajador y 
de su familia. Es la forma, ya sin la norma, porque a la sombra de la norma no se consigue opulencia; es la huella de Caín como paradigma del crimen que es la ciudad.

\section{Metodología}

El proyecto del cual se deriva este artículo de reflexión comenzó como un análisis comparativo de las estéticas de la ciudad metafísica con los subgéneros de la ciencia-ficción occidental del siglo XX, específicamente el space opera, el new wave, el cyberpunk y el steampunk, proponiendo un estudio de las estéticas que presenta la ciudad en la ciencia-ficción apoyado en los subgéneros, ya citados, los cuales presentan sus propias convenciones y estilos descritos en la literatura, el cómic y el cine. El proyecto propició la creación de un producto estético que consistió en una novela construida con textos teóricos, en la que cada capítulo, de manera narrativa, explicaba la convergencia de la ciudad metafísica con los símbolos de ciudad. La ruta investigativa se desarrolló de manera descriptiva, analítica y argumentativa, siguiendo un marco referencial construido desde ocho categorías: libros de estética y metafísica de la ciudad, novelas de ciencia-ficción, libros de cienciaficción relacionados con la ciudad, películas clásicas de ciencia-ficción, series de TV de ciencia-ficción, Juegos de rol y de video con temáticas de ciencia-ficción, obras plásticas y musicales que suelen ser citadas por la ciencia-ficción, comics y novelas gráficas de ciencia-ficción.

De acuerdo con la metodología de esta investigación, se trata, entonces, de dilucidar, en primer, lugar las propiedades estéticas, relacionadas con la esencia de la ciudad (¿qué hace que la ciudad sea estética?), para luego, en segunda instancia, pasar a examinar el despliegue de esta estética, a través del símbolo, en diversas ciudades, reales e imaginarias, por igual. Este artículo se planteó, siguiendo dos referentes: la metafísica de la ciudad, desde donde se buscó establecer los parámetros de una existencia estética de la ciudad; y la semiótica metafísica de René Guénon, que permitió comprender ese sentir de ciudad manifestado desde lo simbólico. Este marco permitió relacionar conceptos metafísicos citadinos como utopía y distopía con símbolos universales como la montaña, el laberinto y la caverna, para concluir en una reflexión sobre el poder que estos símbolos ejercen sobre el ciudadano.

\section{La ciudad y la forma simbólica}

En su libro Símbolos fundamentales de la ciencia sagrada, René Guénon plantea, desde una metafísica no aristotélica sino mística, una pragmática del espacio simbólico de la ciudad, en la cual clasifica de manera comparativa los lugares simbólicos y los homologa como vehículos de ideas tradicionales religiosas. Para Guénon, la metafísica tiene por objeto de estudio de lo arcano, lo misterioso, y el símbolo es la evocación física de ese misterio. Esta propuesta contemplativa se fundamenta en su preocupación por la desdivinización de Occidente, la banalización de las doctrinas orientales y lo que él llama el decrecimiento del simbolismo tradicional de Oriente y Occidente, ya no comprendido por los hombres de un tiempo que ha perdido la mentalidad simbólica. 
Si la metafísica tiene por "objeto" el no-ser y, por eso, es el conocimiento de lo inexpresable, ¿cómo eludir la aporía de "expresar lo inexpresable"? No hay más que dos posibilidades, el uso de términos de forma negativa o el recurso al lenguaje de los símbolos. Encontramos al simbolismo como expresión del conocimiento metafísico - aunque esporádicamente- en la filosofía occidental; Platón, en los Diálogos, recurre con frecuencia a símbolos y mitos cuando intenta expresar ideas metafísicas y en dos de sus epístolas (la segunda y la séptima, sobre todo en esta última) alude directamente a la necesidad del lenguaje simbólico. Lo mismo hace Clemente en Stromata I (Guénon, 1962, 25).

La utilidad y la comprensión de los símbolos es un tema recurrente para Guénon, quien desde una perspectiva completamente religiosa los percibe, no como una representación, sino como una presencia de lo divino en el mundo del hombre. Esta postura esotérica explica que

Su origen es no-humano y se basa en la correspondencia entre dos órdenes de realidades; tiene su fundamento en la naturaleza misma de los seres y las cosas, por eso la naturaleza toda es un símbolo. Símbolos y mitos no son simples recursos estilísticos sino, al contrario, formas indirectas, pero absolutamente auténticas, de traducción de la realidad última. La expresión griega paramythía designa etimológicamente a una prueba superior por medio de un mito, es decir, que el lenguaje mítico, como el simbólico, no es solo designativo sino también probatorio. El símbolo no expresa ni explica, solo sirve de soporte para elevarse, mediante la meditación, al conocimiento de las verdades metafísicas. Su ambigüedad vela y revela la realidad y su carácter polisémico posibilita su interpretación en diversos órdenes o planos de la realidad. Por eso, cada ser humano penetra según sus aptitudes (calificación intelectual) en la intimidad del símbolo. La polisemia es el reflejo sensible universal de la unidad esencial del símbolo. (Guénon, 1962, 26).

Hay entonces un problema generalizado, que consistiría en una negligencia para interactuar con el mundo de los símbolos; pareciera que el símbolo ya no fuera para el hombre una cosa externa - de la divinidad, en este caso-, sino algo propio, de la misma manera que lo puede ser un martillo o un reloj.

El oscurecimiento de los símbolos que caracteriza a nuestra época es el resultado de la pérdida de la mentalidad simbólica, que se refleja en dos tipos de incomprensión, denominados por Guénon incomprensión de primero y segundo grado. El primer grado de incomprensión corresponde a la degradación del sentido de los símbolos (everismo, naturalismo, materialismo); el segundo grado consiste en el estudio exterior de los símbolos. La filosofía profana emplea un lenguaje analítico y racional, la metafísica, ciencia sagrada, usa un lenguaje sintético y espiritual: el simbolismo (Guénon, 1962, 27).

En Símbolos fundamentales de la ciencia sagrada se describen tres símbolos espaciales cuya relación propicia la vida en la ciudad; estos son: la montaña, el laberinto y la caverna. Los tres son símbolos axiales, o sea, que señalan los flujos y las direcciones del universo. La montaña es una elevación que apunta al cielo, un camino ascendente y escarpado, que comienza a ras del piso y llega hasta un punto desde donde ese piso ya no es visible. El viajero que decide escalar la montaña es una persona que tiene su mirada fija en la cima 
y que se visibiliza llegando a esa cima desde donde espera poder contemplar el mundo, y quizá dominarlo. La montaña es un símbolo fundamentalista, relacionado con los dioses, los poderosos y las normas. En la cima del monte Kunlun viven los dioses hinduistas, referenciados tanto por los mismos hinduistas como por el budismo y el taoísmo. En lo más alto del Olimpo hay una ciudad aérea en la que habitan los dioses olímpicos de la antigua Grecia. En la cima del Ararat queda encallada el arca de Noé, después de vagar cuarenta días y cuarenta noches, sobre las olas inmensas que cubrieron el mundo. Moisés sube al monte Sinaí por las tablas de los Díez Mandamientos, mientras que Jesucristo es crucificado entre dos ladrones en lo más alto del Calvario, el cual, según la pintura medieval, tiene forma de calavera. San Juan de la Cruz indica la subida del monte Carmelo como una moraleja para educar al cristiano y ayudarlo en su duro transitar por la vida. Machu Picchu y Chichen Itzá son complejos habitables en los cuales la altura confiere sublimidad. Las pirámides de Imperio Antiguo Egipcio y las pirámides escalonadas mayas y méxicas de Mesoamérica representan montañas.

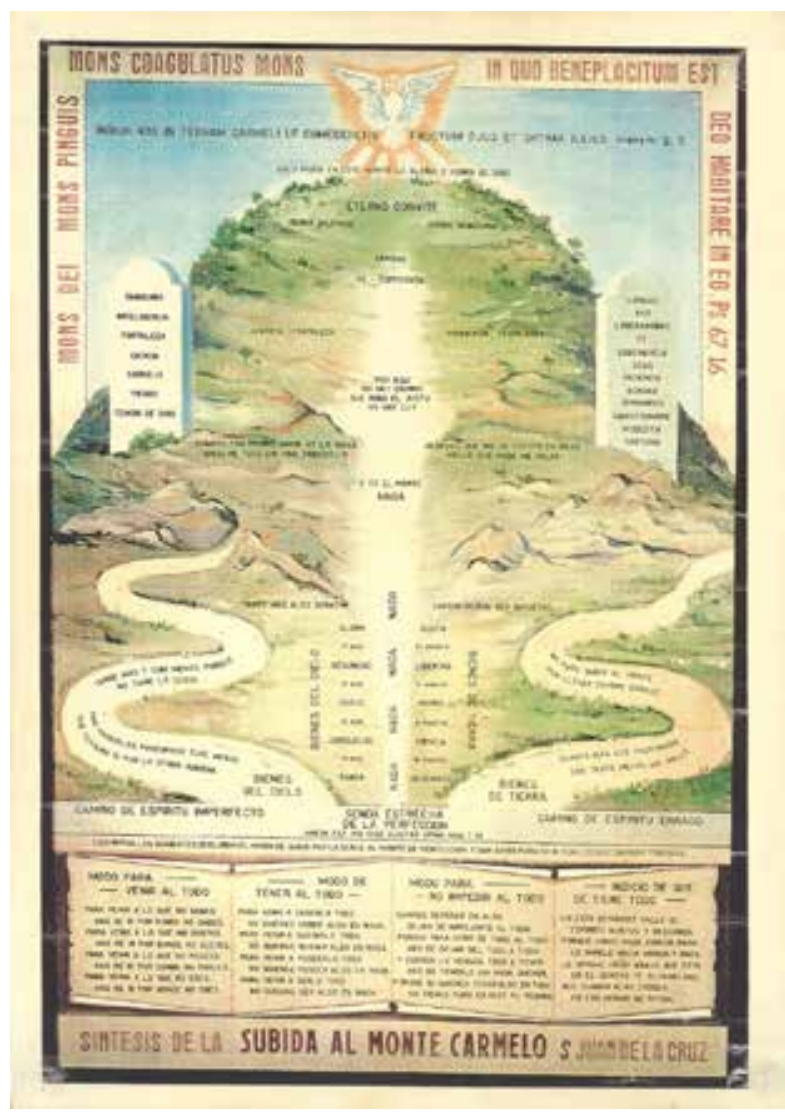

La subida al monte Carmelo, un ejemplo de la montaña como símbolo sagrado de la ascensión metafísica.

Tomado de: http://lacasadegestalt.es/2014/03/subida-al-monte-carmelo/ 
Todo templo es una montaña en medio del pueblo o la ciudad, un puente vertical para alcanzar la divinidad. El Taj-mahal posee esas cualidades de palacio o templo, pero aplicadas a un hermoso patetismo, pues se trata de una tumba. La pirámide de Abraham Maslow es también una montaña que por vía de la autocrítica lleva a la perfección del sujeto, la cual él llamó autorrealización. La montaña es el símbolo cósmico más cabal, dando equilibrio al mundo, el mundo de los dioses y el inframundo; pues se ubica en el mundo -donde vive el hombre-, sirve de escalera al mundo de los dioses - donde viven los dioses-, y forma una barrera que impide que los muertos que vagan en el inframundo invadan el mundo de los seres humanos. La montaña, el monumento y el templo son la misma idea expresada de distinta forma.

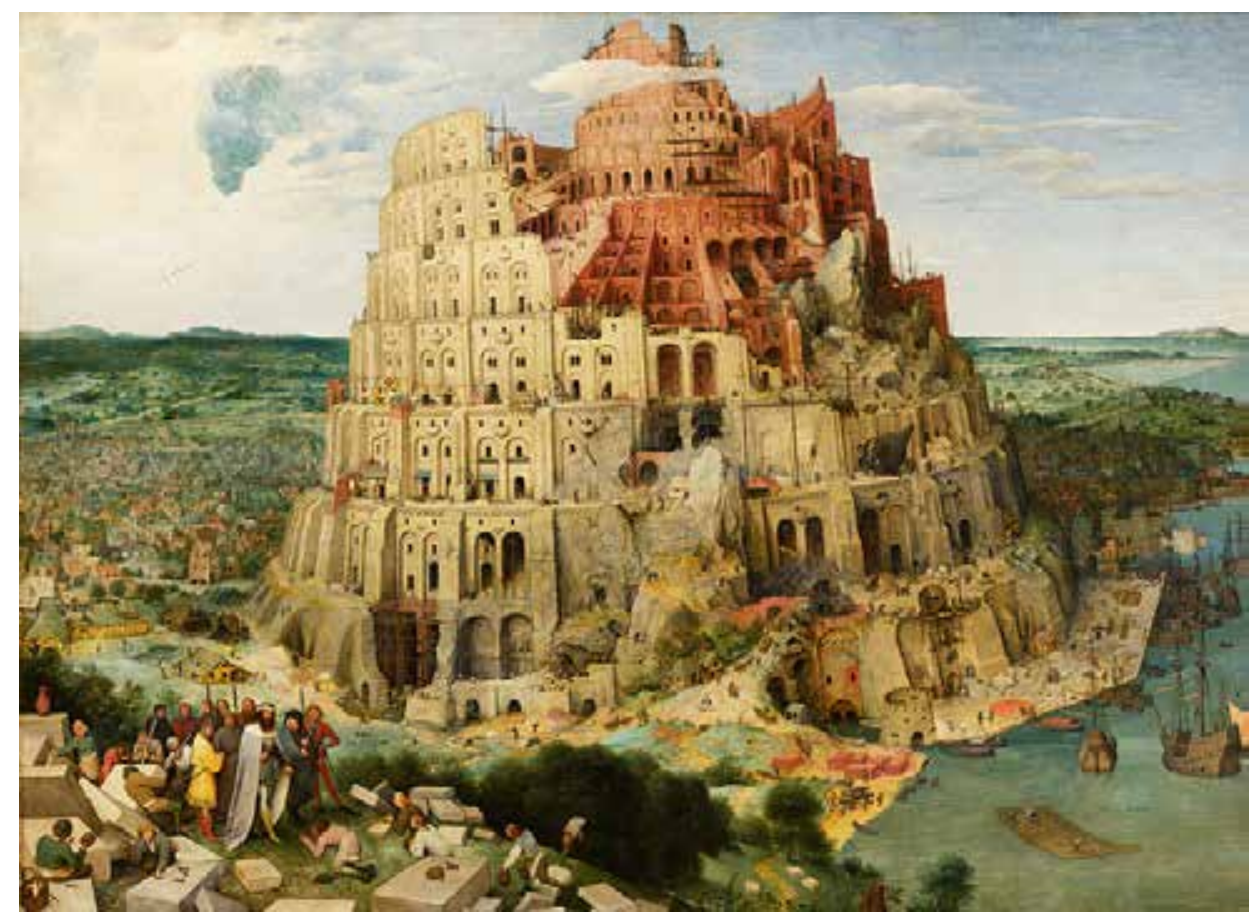

Pieter Brueghel. La gran Torre de Babel. Museo de Historia del Arte de Viena. 1563.

$$
\text { Tomada de http://es.wikipedia.org/wiki/Pieter_Brueghel_el_Viejo }
$$

Guénon identifica una dualidad, semejante a la del yin yang en muchos de los símbolos axiales, o sea los que dan dirección al universo:

Hemos aludido anteriormente a la relación estrecha existente entre el simbolismo de la caverna y el del corazón, lo que explica el papel desempeñado por la caverna desde el punto de vista iniciático en cuanto representación de un centro espiritual. En efecto, el corazón es esencialmente un símbolo del centro, ya se trate, por lo demás, del centro de un ser, o, analógicamente, del de un mundo, es decir, en otros términos, ya se coloque uno desde el punto de vista "microcósmico", ya desde el "macrocósmico"; es, pues, natural, en virtud de esa 
relación, que el mismo significado pertenezca igualmente a la caverna; pero se trata ahora de explicar más completamente esa conexión simbólica misma. (...) esta "caverna del corazón" es el centro vital en el cual reside no solamente el jîvâtmâ, sino también el Atmâ incondicionado, que es en realidad idéntico al propio Brahma, como lo hemos expuesto en otro lugar (Guénon, 1962, 220).

De acuerdo con la metafísica hinduista el Atmâ es el ser, visto de una manera generalizada y el jîvâtmâ o sea el ser individual (que vendría a ser como el yo del psicoanálisis o el alma de la teología) correspondería a la manera particularizada y microcósmica del Atmâ. Entonces la "caverna del corazón" es una metáfora que alude a que el ser (Atmâ) y la individualidad (jîvâtmâ), residen en el corazón de las personas, actuando como polos que equilibran la existencia propia e individual. Ambos están hechos de Brahma ${ }^{7}$, la substancia sagrada de las cosas.

Un simbolismo exactamente similar a este respecto se encuentra, por lo demás, con los Dioscuros, puestos además en relación con los dos hemisferios, uno oscuro y otro claro, como lo hemos indicado al estudiar el simbolismo de la "doble espiral". Por otra parte, aquellos denominados "los dos", o sea el jîvâtmâ y el Paramâtmâ, son también los "dos pájaros" o las "dos aves" de quienes se habla en otros textos diciendo que "residen en el mismo árbol" (así como Árjuna y Krshna montan en el mismo carro), y que están "inseparablemente unidos" porque, como decíamos antes, no son en realidad sino uno y solo ilusoriamente se distinguen; importa destacar aquí que el simbolismo del árbol es esencialmente "axial", como el de la montaña; y la caverna, en cuanto se considera como situada en la montaña, o en el interior mismo de ésta, se encuentra también sobre el eje, pues, en todos los casos y de cualquier modo que se encaren las cosas, allí está necesariamente el centro, que es el lugar de unión de lo individual con lo Universal (Guénon, 1962, 222).

Así Guénon señala otra dualidad propia de la metafísica hinduista, la relación entre el jîvâtmâ y el Paramâtmâ, entre el ser individual y el ser universal, pues en el hinduismo es usual representar al cosmos como una persona, en una visión panteísta, donde universo, divinidad y naturaleza son conceptos inseparables. En concordancia con la visión macrocósmica del Atmâ, el todo a veces se manifiesta como Visnú, señor del conocimiento, la energía y la conservación; y a veces, también, aparece como Krisna, salvador de la humanidad.

En lo más alto de la montaña, o a veces en su interior, se encuentra la caverna. La caverna es el destino final del viaje ascendente por la montaña. En el interior de la caverna se captura la memoria, se guarda lo que se quiere proteger, la familia, el tesoro, los objetos del rito, los prisioneros. La caverna es principalmente un sitio de metamorfosis. Lo que entra a la caverna, cuando sale es diferente, ha sido trasformado. Eso lo aprendimos

7 Aquí la palabra Brahma se refiere a la substancia divina de la que está hecho el universo. A su vez el universo es una suprema existencia, consciente, inteligente y sensible; muy semejante a la de los conceptos del panteísmo occidental. Tomado de: http://global.britannica.com/EBchecked/topic/77039/ brahman 
de los animales que con el cambio de estaciones hacen una caverna o un hueco para protegerse y cuando el clima les es propicio vuelven a salir, con una nueva piel, o donde la oruga entra en crisálida y vuelve al mundo como mariposa. En una gruta usada como portal nació el Niño Jesús. En una caverna tumba su cuerpo muerto se convirtió en un cuerpo vivo. En las cavernas meditan los budas hasta tornarse como dioses. Desde la caverna oscura se mira por la rendija que anticipa el conocimiento del mundo. Pero desde la tradición clásica se llegaba al inframundo por las cavernas y luego con el cristianismo el Hades sería reemplazado por el Infierno. En la tradición judaica el Sheol designaba las profundidades de la tierra, era la habitación desolada donde los muertos descendían. La caverna en la iconografía medieval representaba la entrada a los Infiernos, reemplazando la goela monstruosa. Antes de la resurrección Jesús descendió al infierno, rompió los portones de la caverna donde estaban presos los justos que desde Adán habían muerto y los liberó, cómo lo cuenta la Leyenda Áurea:

La noche eterna del Infierno se volvió súbitamente resplandeciente cuando Cristo allí descendió. Los porteros acorazados de hierro se dijeron unos a otros en aquella silenciosa penumbra: ¿quién es este tan terrible y tan esplendoroso que acaba de llegar? Nunca nuestro abismo acogió alguien así, nunca el mundo vomitó algo igual en nuestra caverna (Varazze, 2003, 326).

La caverna, la olla y la caja son la misma idea expresada de forma diferente. Dentro de la caverna está el cambiante, el hombre consciente de su mutación. El viaje de nuestra vida empieza en una caverna, el interior de nuestra madre y termina en otra caverna, un hueco de tres metros en el piso. La caverna es el espacio privado por autonomía, el lugar de meditación donde los hombres se hacen santos o villanos, donde la luz penetra sutilmente, revelando, mostrando verdades. Las casas y edificios donde vivimos son cajas que atestiguan la transformación efectuada por el tiempo. La caja es mutabilidad, pero también puede ser inmutabilidad; por ejemplo, la caja fuerte cambia a un objeto desprotegido a protegido, permitiendo seguridad en todo momento, postergando su deterioro, evitando su cambio por el tiempo. La caverna es ágora, teatro y panóptico de acuerdo con el rango ético que se despliegue en la ciudad. La caverna es el corazón del cosmos, el sito donde se encuentran los cuatro puntos cardinales, evidenciado en el centro de la cruz.

Es preciso, empero, advertir también, para "situarlos" exactamente uno respecto del otro, que la montaña tiene carácter más "primordial" que la caverna: ello resulta del hecho de que es visible en el exterior, de que es inclusive, podría decirse, el más visible de todos los lugares, mientras que, al contrario, la caverna es, según lo hemos dicho, un lugar esencialmente oculto y cerrado. Puede fácilmente deducirse que la representación del centro primordial por la montaña corresponde propiamente al período originario de la humanidad terrestre, durante el cual la verdad era íntegramente accesible a todos (de donde el nombre de Satya-Yuga ['período de la verdad'], y la cúspide de la montaña es entonces el Satya-Loka o 'lugar de la verdad'); pero, cuando a consecuencia de la marcha descendente del ciclo esa verdad no estuvo ya sino al alcance de una minoría más o menos restringida (lo que coincide con los comienzos de la iniciación entendida en su sentido más estricto) y se hizo oculta para la mayoría de los hombres, la caverna fue un símbolo 
más apropiado para el centro espiritual y, por consiguiente, para los santuarios iniciáticos que son su imagen (Guénon, 1962, 224).

El laberinto también lleva a la caverna, pero viaja en dirección opuesta, se hunde en el terreno como un embudo. La dirección también cambia; ya no es una sola, pues son muchas que llevan a otras muchas, contenidas en la sola figura del embudo. Un laberinto tallado en una puerta hacía reconocibles los sitios donde se efectuaban los rituales de iniciación. Cada imagen del laberinto estaba acompañada de una adivinanza cuya resolución permitía el acceso a los misterios de la sabiduría. Laberinto y adivinanza convergen en la figura del monstruo. Monstruosa es la esfinge con cabeza y pechos de mujer, alas de águila, cuerpo de león y cabeza de serpiente en la cola, que a la entrada de Tebas devoraba a quien no descifraba su acertijo. Un monstruo es también el minotauro que acechaba en el centro del laberinto de Minos. Los laberintos con forma de embudo son motivo arquitectónico de algunas catedrales cristianas en donde simbolizan el paso del desconocimiento al conocimiento. Los ingleses lo cultivaron como parte del arte de la jardinería, creando laberintos de arbustos donde los niños podían jugar.

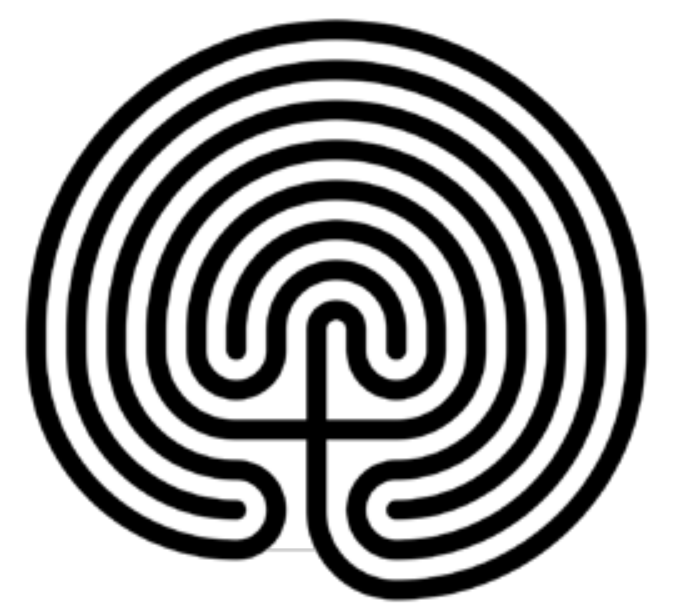

El laberinto en forma de embudo, es un motivo clásico del mundo antiguo que simboliza el descenso en busca de lo misterioso.

Tomado de http://www.nathanaelsrest.com.au/labyrinth/

En el laberinto todo se mezcla, incluso lo orgánico con lo mecánico; por eso no es de extrañar el tema del hombre-ciudad o la ciudad-hombre, en el cual el sujeto es asimilado por su propio dispositivo social, aludiendo a una fusión metafórica. Por ejemplo en Ciudad de Cristal (1985), Paul Auster cuenta la historia de Daniel Quinn que ha perdido a sus seres queridos y que, en medio de su desesperación, comienza a escribir novelas de detectives bajo el seudónimo de William Wilson. Su vida, estancada en la rutina, será interrumpida por una llamada equivocada; alguien, en el teléfono, le pregunta por Paul Auster el detective, y ante la persistencia, Quinn decide tomar la identidad del detective Auster, e inicia su nueva y emocionante vida. Consiguiente a este drama, Auster escribe: 
Nueva York era un espacio inagotable, un laberinto de interminables pasos, y por muy lejos que fuera, por muy bien que llegase a conocer sus barrios y calles, siempre le dejaba la sensación de estar perdido. Perdido no solo en la ciudad, sino también dentro de sí mismo. Cada vez que daba un paseo se sentía como si se dejara a sí mismo atrás, y entregándose al movimiento de las calles, reduciéndose a un ojo que ve, lograba escapar a la obligación de pensar. Y eso, más que nada, le daba cierta de paz, un saludable vacío interior (Auster, 1985, 5).

Es propia del laberinto la confusión de identidades, o la confusión en general. La similitud entre el hombre y la ciudad, al aducir que es posible perderse en la ciudad o en sus pensamientos. El hombre es la ciudad y la ciudad es el hombre. Como en la Metrópolis (1927) de Fritz Lang, hay una unión tensa entre lo orgánico y lo mecánico; la masa humana de obreros es inseparables de las máquinas con las que trabajan, la mujer es robot y el robot es la mujer. Hoy se habla del corazón de la ciudad, del pulmón de la ciudad. Somos casi inseparables de nuestros laptops, teléfonos móviles y automóviles, auténticas prótesis contemporáneas.

El laberinto también es rompecabezas, puesto que sus componentes desiguales tienen una doble naturaleza: una cuando se perciben desarmados y otra cuando configuran una forma. Los monstruos no solo viven en laberintos, sino que son rompecabezas vivos, ya que cada componente de sus cuerpos es desigual. La idea del rompecabezas no es nueva. Perseo necesitó para derrotar a medusa, el yelmo de Hades que hacía a su portador invisible, el escudo invencible de Atenea y las botas aladas de Hermes. Distintos componentes para estructurar la forma de destruir la Gorgona. El laberinto es el símbolo caótico más implacable, desequilibrando el mundo, el inframundo y el mundo de los dioses, pues puede entenderse como un embudo, pero también como un vórtice, implicando un símbolo caótico de desorden y desconfiguración radical. Laberinto, adivinanza y rompecabezas son la misma idea, expresada de distinta forma.

René Guénon se encontró en desavenencia con el autor W. F. Jackson Knight y su explicación científica y psicológica del porqué del laberinto, en el pasaje del libro VI de la Eneida donde se describen las puertas del antro de la Sibila de Cumas, marcadas con un grabado que muestra el laberinto de Creta y su origen, sitio que para Guénon está unido con los ritos la antigua Grecia, no por inconscientes colectivos, sino por cadenas del conocimiento que los iniciados han construido de manera oral y gestual.

Esta idea, según la interpretación que el autor da de hechos concordantes pertenecientes a épocas y regiones muy diversas, habría estado originariamente en relación con los ritos funerarios y luego, en virtud de cierta analogía, habría sido transportada a los ritos iniciáticos; volveremos más en particular sobre este punto en lo que sigue, pero debemos antes formular algunas reservas sobre el modo en que el autor concibe la iniciación. Parece, en efecto, encararla únicamente como un producto del "pensamiento humano", dotado por otra parte de una vitalidad que le asegura una especie de permanencia a través de las edades, aun si a veces no subsiste, por así decirlo, sino en estado latente; no tenemos necesidad alguna, después de todo cuanto hemos ya expuesto acerca de este asunto, de 
mostrar una vez más la insuficiencia de ese punto de vista, ya por el solo hecho de que no tiene en cuenta los elementos "sobrehumanos", que en realidad constituyen precisamente lo esencial. Insistiremos solo en esto: la idea de una subsistencia en estado latente trae aparejada la hipótesis de una conservación en un "subconsciente colectivo", tomada de ciertas teorías psicológicas recientes; como quiera que se opine acerca de éstas, hay en todo caso, en la aplicación así efectuada, un completo desconocimiento de la necesidad de la "cadena" iniciática, es decir, de una transmisión efectiva e ininterrumpida (Guénon, 1962, 212).

La iniciación es la acción que inicia el viaje, el acceso a un conocimiento hermético, a un poder que yace en la caverna y que puede ser aprehendido en el contexto del rito. Entonces, en el fondo del laberinto hay una caverna. El viaje fue bajo tierra, pero el punto de llegada es el mismo, iniciación en la caverna. Si la montaña es la vía al conocimiento que sueña el fundamentalista, la de la visión heroica inmutable que mira hacia arriba con estimación y respeto a la norma, el laberinto es la vía al conocimiento que sueña el constructivista, la de la visión que se adapta a los cambios constantes, que mira en todas las direcciones encontrando el conocimiento en todos los que están alrededor.

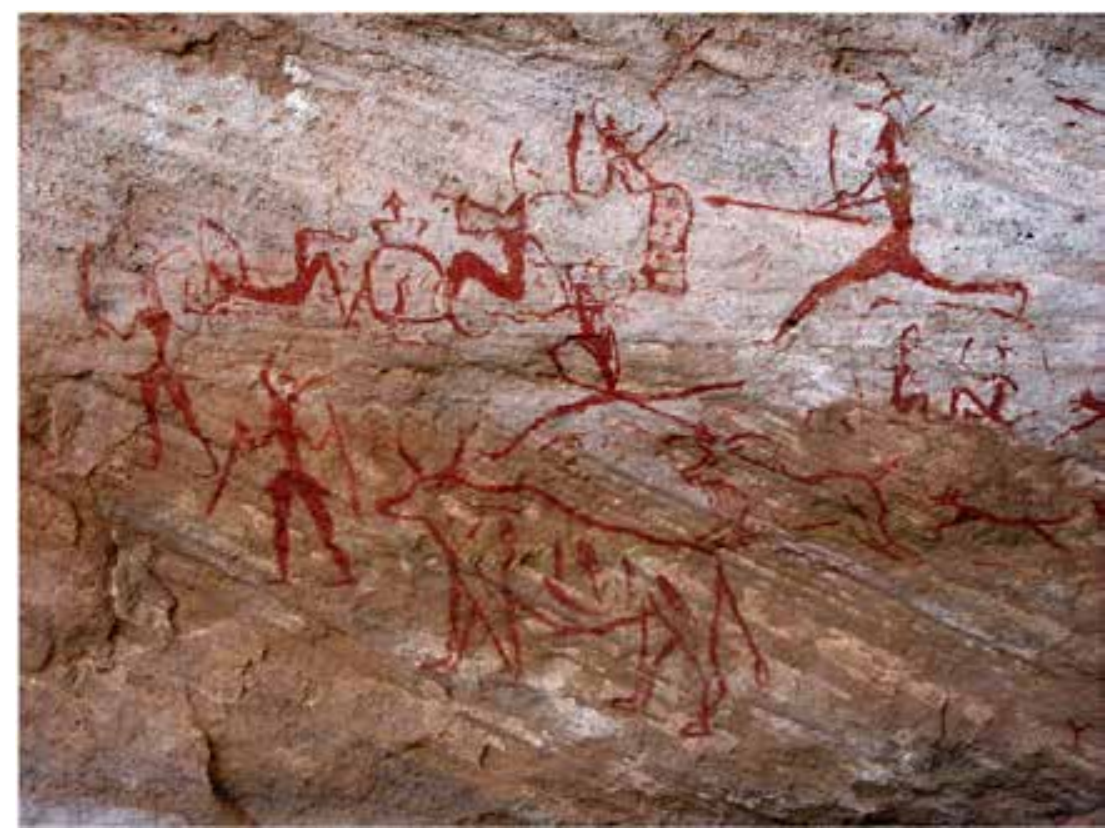

La caverna es el sitio que contiene la memoria. Tiene el poder de la transformación activa o inactiva de las cosas. Cavernas de Chauvet en el sur de Francia.

Tomado de https://annadoherty.wordpress.com/2012/10/06/history-of-animation-cave-paintings/

La montaña, el laberinto y la caverna son imágenes mentales en las que la ciudad se manifiesta en su dualidad de mito antiguo y modernidad técnica. Igualmente son imágenes que pueden ser categorizadas como imágenes dialécticas. Dice Zarone: 
Walter Benjamin ha reflexionado con intensidad sobre una filosofía del tiempo de la ciudad, susceptible de resumirse en un concepto, el de "imagen dialéctica", que es dialéctica por ser íntimamente fenomenológica. En la imagen dialéctica, lo sido de una determinada época es siempre, al mismo tiempo, "lo siempre ya sido". Pero esto mismo se manifiesta cada vez como tan solo a los ojos de una época absolutamente determinada: aquella en que la humanidad se frota los ojos y reconoce como tal justamente esta imagen de sueño (Zarone, 1988, 19).

Esta teoría benjaminesca, que relaciona Zarone con la metafísica de la ciudad, es llamativa porque excluye el concepto instituido de que es la memoria, desde dentro, la que domina el presente y afirma que, al contrario, son los derechos del ahora sobre la memoria, los que se reclaman a través de la imagen. Esta memoria es desde luego la memoria "involuntaria"8 de Proust. Para Benjamin la imagen dialéctica no evoca una verdad del tiempo histórico universal, sino una verdad del tiempo histórico privado; es como un sueño que irrumpe, y que excede el lenguaje, o sea, que no se puede poner en palabras; está relacionada con el pasado verdadero, no el histórico, que es el pasado que despierta y sorprende, por agradable o desagradable que sea; está relacionada con el tiempo discontinuo, no con el tiempo lineal de los cronogramas. La imagen dialéctica al pertenecer a un tiempo no lineal y subjetivo, trabaja distinto a los dispositivos mnemotécnicos convencionales, pues permite la unión de los conceptos que históricamente han estado separados por el tiempo, como lo han sido el mundo de la técnica y el arcaico universo simbólico de la mitología, queriendo decir que las imágenes de orden de los antiguos imperios como el egipcio o el griego forman parte de la estructura originaria de la metrópolis violenta, desarraigada y nihilista, queriendo decir también que el ahora de la metrópolis es una herida originada por la vida inmóvil del hombre en el mundo; ordenador y constructor, heredero de Caín.

\section{La narración fundamentalista y constructivista en la ciudad}

Néstor García Canclini identificó, a finales del siglo veinte, un paulatino proceso de globalización de intención económica, que llevaría a una inevitable multiculturalidad en el ámbito mundial. Las estéticas y las éticas de este hecho ya han sido ampliamente experimentadas a través del auge de las redes sociales y de la proliferación de una comunicación inmediata y fragmentada. Desde los albores de la Modernidad la ciudad ha sido el escenario del enfrentamiento entre dos corrientes: la fundamentalista que defiende las identidades nacionales, y la constructivista que se articula a lo global en la construcción de un patrimonio común multicultural. Estas corrientes, según García Canclini, son los polos constituyentes de la globalización, y son referentes vigentes para interpretar la identidad de los ciudadanos, en el contexto de la existencia en una ciudad cambiante.

8 La memoria involuntaria es un subcomponente de la memoria, que se manifiesta cuando elementos encontrados en la cotidianidad evocan recuerdos del pasado sin hacerse un esfuerzo consciente. La memoria voluntaria, es su opuesto binario, y está caracterizada por el esfuerzo deliberado de recordar el pasado. 
En verdad, esta oposición entre el discurso constructivista de los estudios culturales y las doctrinas fundamentalistas de los movimientos étnicos o nacionales es reciente. Si seguimos los vínculos de la literatura, la filosofía y la antropología con el fundamentalismo en los últimos dos siglos, hallamos fuertes complicidades. El romanticismo folclórico y el nacionalismo político se aliaron para lograr que las tradiciones de los agolpamientos étnicos y socioculturales quedaran ordenadas en menos de doscientos envases jurídicoterritoriales que llamaron naciones. Se estableció que los habitantes de un cierto espacio debían pertenecer a una sola cultura homogénea y tener por lo tanto una única identidad distintiva y coherente. La cultura propia se formaría en relación con un territorio y se organizaría conceptual y prácticamente gracias a la formación de colecciones de objetos, textos y rituales, con los que se afirmarían y reproducirían los signos que distinguen a cada grupo (García, 1995, 92).

La narración de la ciudad en la Modernidad ha cambiado. El héroe -que aparece como prócer o soldado-y el mago -que se reinventa como el científico-son patrimonios propagandísticos del fundamentalismo, que narran un relato común, basado en hazañas y descubrimientos, que luego serán inmortalizados en los monumentos. El fundamentalismo propone una historia catalizada por unos pocos individuos idealizados, cuyo destino es inseparable de los grandes momentos de la historia. Con la llegada de la globalización una inevitable visión comparativa se desarrolla, desvirtuando la narración fundamentalista, por ejemplo, cuando una visión histórica rigurosa demuestra la inexistencia de personajes clave en la liberación de un país, al igual que lugares o situaciones cultivados por la tradición. Ante esta situación García Canclini advierte que el fundamentalismo se disfraza de cosmopolitismo, ofreciendo productos culturales supuestamente multiculturales, pero que en verdad son tan rígidos como los del fundamentalismo.

Me pregunto si en el desplazamiento de las monoidentidades nacionales a la multiculturalidad global, el fundamentalismo no intenta sobrevivir ahora como latinoamericanismo. Siguen existiendo, como dijimos, movimientos étnicos y nacionalistas en la política que pretenden justificarse con patrimonios nacionales y simbólicos supuestamente distintivos. Pero me parece que la operación que ha logrado más verosimilitud es el fundamentalismo macondista: congela lo "latinoamericano" como santuario de la naturaleza premoderna y sublima a este continente como el lugar en el que la violencia social es hechizada por los afectos (García, 1995, 94).

La identidad ha sido un imaginario cultivado desde los organismos socio-políticos los cuales buscaban sustentar su poder desde la divulgación de unas supuestas verdades, impuestas desde los medios. Antes la identidad era un nacionalismo, una bandera, un himno, un plato típico o una artesanía. Sin embargo, han sido la academia, con su aproximación a la cultura que la globalización ha producido.

La identidad aparece, en la actual concepción de las ciencias sociales, no como una esencia intemporal sino como una construcción imaginaria. La globalización disminuye la importancia de los acontecimientos fundadores y los territorios que sostenían la ilusión de identidades ahistóricas y ensimismadas. Los referentes identitarios se forman ahora, 
más que en las artes, la literatura y el folclor, que durante siglos dieron los signos de distinción a las naciones, en relación con los repertorios textuales e iconográficos provistos por los medios electrónicos de comunicación y la globalización de la vida urbana. ¿Qué significan, dentro de este proceso, las construcciones imaginarias que lo contradicen? (García, 1995, 95).

Entonces hay un cuadro proclive a la aparición de una nueva narración, que concuerde con las nuevas formas de la ciudad. Ya el motor del relato no es la búsqueda del conocimiento viajando en una dirección (montaña), o en varias (laberinto), sino la búsqueda de la satisfacción a través del consumo. Para empezar, ya el que deambula en pos de algo no es el héroe, es el hombre común del relato constructivista, por ejemplo, en específico el fláneur el viajero de la ciudad, quien ejerce el consumo más primordial de todos, el de la mirada. Es el viajero que mira y luego crea una memoria de lo que ha mirado, la crónica.

Ser fláneur, anota Ramos, no es sólo un modo de experimentar la ciudad. "Es, más bien, un modo de representarla, de mirarla y de contar lo visto. En la flanería el sujeto urbano, privatizado, se aproxima a la ciudad con la mirada de quien ve un objeto en exhibición. De ahí que la vitrina se convierta en un objeto emblemático para el cronista". El paseo es una operación de consumo simbólico que integra los fragmentos en que ya se despedazaba esta metrópoli moderna. Al narrativizar los segmentos urbanos en la crónica, se construye —mediante lo que Ramos llama "la retórica del paseo" — un orden de la ciudad. La crónica publicada en los periódicos es el medio decomunicación propio de esta modernidad incipiente, donde se enlazan los sentidos parciales de las experiencias urbanas (García, 1995, 98).

Traduciendo la antigua metáfora, antes señalada por Guénon, a esta situación -desdivinización de la ciudad, negligencia simbólica- la montaña actual sería la sublimidad del centro comercial que se alza dominando sobre la ciudad, y su acción transformadora se daría en sus múltiples locales que obrarían como cavernas. García Canclini aduce que el consumo sirve para pensar. Y esa postura tendría significación a la hora de investigar el despliegue de la ciudad, entendido ya no como relato metafísico, sino como relato físico consumista, que viene originándose desde la Revolución Industrial y que se fortaleció desde que los proyectos modernos de humanismo cayeron para dejar solo una consciencia que busca en el consumo el sentido de una experiencia individual y colectiva. El consumo, susceptible de ser educado y parte de la vida privada y pública, es una acción en la se revelan gustos y afinidades que configuran identidad, pero en el consumo también hay una convergencia entre el disfrute y la necesidad, presentada a través de un relato imaginario, en el cual subyacen las carencias y miedos que acontecen actualmente en la ciudad.

Al igual que la montaña, el laberinto se revela de una manera, tal vez, más evidente. La incertidumbre, el vértigo y la constante inevitabilidad son las sensaciones de ciudad que se exteriorizan en lo urbano, articulando un relato efímero, fragmentado y poco sólido, laberíntico podría decirse.

Las grandes ciudades desgarradas por crecimientos erráticos y una multiculturalidad conflictiva son el escenario en que mejor se exhibe la declinación 
de los metarrelatos históricos, de las utopías que imaginaron un desarrollo humano ascendente y cohesionado a través del tiempo. Aun en las urbes cargadas con signos del pasado, como la capital mexicana, el agobio del presente y la perplejidad ante lo incontrolable del porvenir reducen las experiencias temporales y privilegian las conexiones simultáneas en el espacio. [... . tal vez sea ésta una de las razones por la que los movimientos emancipadores basados en las grandes narraciones históricas (el proletariado, las naciones) pierden eficacia y en cambio ganan rating los movimientos sociales urbanos, las acciones fragmentarias y fugaces. (García, 1995, 100).

Ahora la ciudad es como el Aleph de Borges, un punto que contiene todos los puntos del universo. ¿Quiénes están en la ciudad?, todos; ¿qué sucede en la ciudad?, todos los hechos y acontecimientos posibles; ¿cuál es el ritmo de la ciudad?, todos los ritmos aparecen de manera simultánea. La experiencia caótica del laberinto domina cualquier intención narrativa que el fundamentalismo hubiera intentado perpetuar, porque ya no hay tiempo ni espacio que fluyan en línea recta; el vórtice de la vida sacude por igual a todos, equiparándolos, en el desorden y lo pasajero.

Narrar es saber que ya no es posible la experiencia del orden que esperaba establecer el fláneur al pasear por la urbe a principios de siglo. Ahora la ciudad es como un videoclip: montaje efervescente de imágenes discontinuas. Ya no podemos recorrer los veinte kilómetros hasta el centro como cuando íbamos en el autobús y un relato de Carlos Fuentes o el Kalimán lo volvían pacífica sala de lectura. Todavía algunos insistimos en espiar las noticias del periódico o la fotonovela, pero pronto las frenadas constantes del autobús o los apretujones del metro nos hacen desistir (García, 1995, 100-101).

\section{Conclusión. En pos de nuevos símbolos, nuevas realidades}

Esta investigación se originó con la intención de pensar de manera diferente la ciudad, pues la búsqueda de diferentes perspectivas sobre este tema continúa siendo relevante para las ciencias humanas y sociales, por la necesidad de comprender la inminente liquidez de la sociedad, la diversidad de sus huellas, y la posibilidad de llegar a una percepción del símbolo que, aunque de manera transitoria, sirva de referencia al aquí y ahora. Para alcanzar este propósito se evitaron los acercamientos más usuales, los de la materialidad de la ciudad, los cuales están circunspectos a aspectos culturales o arquitectónicos, apuntando al contrario, al discernimiento de la metafísica de la ciudad, y su percepción a través del símbolo, el cual para semiólogos como Guénon, es una manifestación de algo que está más allá, algo que no se ve, pero está allí.

Antes que nada, pensar la ciudad y sus símbolos implica meditar las relaciones que establecemos desde temprana edad con las instituciones fundamentalistas y constructivistas: las primeras, comunicando una agenda de jerarquías que busca seguidores confiados y obedientes; y las segundas para fomentar y construir unas actitudes sociales equitativas y de responsabilidad, muy próximas a los objetivos humanistas de la academia. La identidad depende de la identificación con esos símbolos, los cuales hablan de algo que se piensa, se siente y se comparte con otros, siendo entonces el símbolo, el elemento fundamental 
de unidad que permite que haya comunidad. El símbolo también es una vía que comunica las acciones que un grupo de personas quiere que se cumplan; es una invitación a actuar, abstenerse o inhibirse en grupo, momentos en los cuales un objeto del campo estético, el símbolo, promueve formas particulares de procedimiento, cuya valoración pertenece al campo de lo ético.

De esta manera el símbolo es la exteriorización de una percepción, de una sensibilidad susceptible de convertirse en acción. Un asunto de estética llevado a la ética, pues es el símbolo el que puede llevar a que pasen cosas. Esto lo comprenden los poderosos (políticos y religiosos, luego economistas) y, por lo tanto, ellos buscan usar el símbolo para perpetuarse en el poder; además, son ellos los que tienen la capacidad económica para comprar a los que construyen el símbolo, llámense artistas, publicistas o diseñadores. El símbolo persuade, convence y hace que una mentira sea percibida como una realidad. Entonces, ¿qué hacer frente a esto?, ¿es posible que la ciudad esté condenada a ser un escenario donde se ejerce el poder sin equidad y sin posibilidad de transformación social?

Favorablemente la teoría del ciudadano constructivista de García Canclini es compatible con la teoría pedagógica del educador Herbert Read, pues ambas concluyen en la realidad como construcción colectiva desde la sensibilidad. Esta relación sirve de coyuntura para proponer una hipotética solución a la problemática del símbolo en la ciudad, desde el campo de la educación, y a la vez anticipar un proyecto futuro de investigación que valide la aplicabilidad de esta solución. Read afirma que lo estético y lo ético tienen punto de encuentro en el campo de la educación, proponiendo un modo de enseñanza que estratégicamente empieza con la experiencia estética, sensibilizando a los niños con el arte, los símbolos y el diseño, y que luego pasa a cultivar lo racional y los valores. Dice Morales Ardaya:

Parece que fue Platón el primero que propuso este vínculo de modo explícito, o por lo menos, el primero que le dio justificación teórica. Así, en La república y en Las leyes afirma que los principios estéticos que deben guiar las representaciones artísticas deben ser apropiados para contribuir a que los hombres se acostumbren a percibir la armonía entre los seres, las esencias verdaderas, lo que trasciende a la realidad física perecedera y multiforme. Por lo mismo, tales representaciones han de ser las más convenientes para desarrollar en los hombres las bases de la conducta moral. (Morales, F., 2001: 83).

Es importante tener en cuenta que esta propuesta de una educación estética iba más allá del reconocimiento de autores y de obras de arte, pues se tenía como objetivo una sensibilización del individuo, de sus percepciones y de sus relaciones con otros seres humanos. ¿No es entonces esto lo que hace falta para hacer frente a los conflictos que plantea la ciudad? Toda relación humana empieza y termina con la sensibilidad, cualidad, entendida como una receptibilidad, que permite "ponernos en los zapatos del otro", y que es capaz de colocar en perspectiva cualquier problema de lógica o ética, ampliando, así, las posibilidades de su solución. 
Dice Herbert Read: Debe comprenderse desde el comienzo que lo que tengo presente no es simplemente la "educación artística" como tal, que debiera denominarse más apropiadamente educación visual o plástica: la teoría que enunciaré \{la educación por el arte\} abarca todos los modos de expresión individual, literaria y poética (verbal) no menos que musical o auditiva, y forma un enfoque integral de la realidad que debiera denominarse educación estética —la educación de esos sentidos sobre los cuales se basan la conciencia y, en última instancia, la inteligencia y el juicio del individuo humano. Solo en la medida en que esos sentidos establecen una relación armoniosa y habitual con el mundo exterior, se construye una personalidad integrada. Sin semejante integración, no solo tenemos tipos psicológicamente desequilibrados familiares al psiquiatra, sino - y esto es más desastroso desde el punto de vista del bien general—, esos sistemas arbitrarios de pensamiento, de origen dogmático o racionalista, que a pesar de los hechos naturales tratan de imponer sobre un mundo de vida orgánica un patrón lógico o intelectua. (Morales, F., 2001: 84-85).

Igualmente es importante señalar que esta idea, de tranversalización entre lo estético, lo ético y lo educativo, no es moderna, pues encuentra su origen en la antigua sociedad griega, sin que Platón sea necesariamente el padre de la misma, pues era de común acuerdo entre los griegos que el ejercicio de las artes era indispensable en la formación del ciudadano. Como se expresa los diálogos de Platón, el Protágoras (1981, t. 4: 325c- 326b):

Comenzando desde niños, y mientras vivan, los enseñan y los reprenden. Apenas comienzan a comprender lo que se les dice, nodriza, madre, pedagogo, y aun el padre mismo, todos se empeñan en que el niño resulte óptimo; respecto de cada obra y palabra le enseñan y señalan "esto es justo", pero "estotro es injusto"; "esto es bello", "estotro, feo"; "esto es pío", "estotro, impío"; "haz esto", "no hagas esto" [...] Después, envíanlos a la escuela, recomendando a los maestros que pongan mucho mayor cuidado en la buena conducta de los niños que en letras y cítara. Esméranse en ello los maestros, y cuando han aprendido las letras y van ya a entender lo escrito [...], danles, sentados ya, a leer obras de buenos poetas y fuérzanlos a que las memoricen que, en ellas, hay muchas advertencias, descripciones, alabanzas y encomios de antiguos y buenos varones; así el niño, por emulación, los imitará y anhelará hacerse como ellos. A su vez, los maestros de cítara [...] se cuidan grandemente de moderar a los jóvenes para que no hagan nada malo; además, en habiendo aprendido cítara, enséñanles obras de otra clase de buenos poetas: los melódicos, extendiendo así sus conocimientos en cítara; y se esfuerzan en que ritmos y armonías se aposenten en las almas de los niños para que los domestiquen y, domesticados por bellos ritmos y bellas armonías, resulten aprovechados en hablar y obrar, porque la vida entera del hombre ha de ser rítmicamente bella y armoniosamente bella (Morales, F., 2001: 83-84).

Educar para interactuar con el símbolo, comprender sus intenciones y consecuencias permitirá al ciudadano una mayor comprensión de los procesos políticos y económicos que lo rodean; además, propiciará el fortalecimiento de la autonomía, la construcción de la identidad y la participación en las decisiones colectivas, sin ser sesgado por el mensaje que el poder establecido divulga desde el símbolo. Hacer parte de la ciudad es también empoderarse de los símbolos que la constituyen; conocerlos, interpretarlos y usarlos hace también parte de los derechos y deberes del ciudadano, y su uso principal es como 
dispositivo mnemotécnico. La memoria de la ciudad depende completamente de la preponderación de lo simbólico, ¿qué se recuerda?, ¿qué se olvida?, ¿qué idea prospera?, ¿qué idea mengua? En una situación como la actual en que la memoria que habla de nuestro tiempo ha tenido tendencia a desaparecer, porque no la hemos fabricado en materiales resistentes como la piedra o el mármol, es importante que se conozca la naturaleza del símbolo para que la generación de la memoria sea valorada y asegurada, siguiendo los parámetros aplicables a un patrimonio significativo. De este empoderamiento se posibilitará una lectura diferente de la ciudad como composición de símbolos, ya no como utopía o distopía, ya no como reflejo del mito, sino como una realidad vibrante, múltiple y contradictoria. Como máquina procreadora de realidades incluyentes, comunicadas a través de nuevas construcciones simbólicas.

\section{Fuentes}

\section{Filmografía}

Melnick, D. (Productor), E Russell, K. (Director). (1980). Altered States [Película]. Burbank., California: Warner Bros.

Pommer, E. (Productor), E Lang, F. (Director). (1927). Metropolis [Película]. República de Weimar; Alemania: UFA.

Taicher, R. (Productor), E Jodorowky, A. (Director). (1973). The Holy Mountain [Película].

México D.F; México: ABKO.

Thomas, E. (Productor), E Nolan, C. (Director). (2010). Inception [Película]. Burbank., California: Warner Bros.

\section{Fuentes Impresas}

Agustín de Hipona (Santo) (1978) Obras de San Agustín - La Ciudad de Dios. Madrid: Biblioteca de Autores Cristianos. Escrito en 426 A.D.

Alighieri, D. (1999) Divina comedia. Barcelona: Espasa.

Auster, P. (1985). Ciudad de Cristal. Barcelona, España: Anagramas.

Campanella, T. (2007) La Imaginaria Ciudad del Sol. Madrid: Tecnos.

Covarrubias, Sebastian de (1943). Tesoro de la lengua castellana o española. Barcelona: Horta.

Cruz, Juan de la (Santo) (2007) Subida del monte Carmelo. Buenos Aires: Editorial San Pablo.

García Canclini, N. (1995) Consumidores y ciudadanos. México: Editorial Grijalbo.

Guénon, R. (1962). Símbolos fundamentales de la ciencia sagrada. Compilación póstuma establecida y presentada por Michel Vâlsan. Recuperado de https://docs.google.com/viewer?a $=v E$ Epid $=$ sitesEsrcid =ZGVmYXVsdGRv6WFp6nxz625pZG95Y29s63J8Z3g6NWJkOWOxOTNjNDkwNjE5OO

Heidegger, M. (1994). La pregunta por la técnica. En Autor, Conferencias y Artículos (pp. 9-37).

Barcelona, España: Ediciones del Serbal.

Milton, J. (2009) El paraíso perdido. Barcelona: Espasa.

Morales Ardaya, F. (2001). ¿Debe ser bueno lo bello?: Apuntes sobre la relación entre lo estético y lo ético. Revista Contexto, Volumen 5 (Número 7), pp. 73-88. 
Moro, T. (2004) Utopía. Madrid: Alianza Editorial.

Platón (1981). Obras Completas. Traducción, prólogo y clave hermenéutica de Juan David García Bacca. Tomo IV: Parménides, Protágoras, Filebo. Caracas: Coedición de la Presidencia de la República y la Universidad Central de Venezuela.

. (2000) Critias, en Diálogos VI. Madrid: Gredos.

(2012) Alegoría de la caverna, en República VII. Madrid: Alianza Editorial.

Read, H. (1959). Educación por el arte. Versión castellana de Luis Fabricant. 2. ${ }^{a}$ ed. Castellana. Buenos Aires: Paidos.

Sófocles (2004) Antígona. Buenos Aires: Losada.

Varazze, Jacopo de. (2003). Legenda Áurea. Vidas de Santos. Sao Paulo: Companhia das Letras.

V. AA. Las mil noches y una noche (2013) Reino Unido: Usborn Publishing.

V. AA. La Biblia (1984) Bogotá: Ediciones Paulinas.

\section{Bibliografía}

Bauman, Z. (2009) Modernidad Liquida. Buenos Aires: Fondo de Cultura económica.

Benjamin, W. (1996) La dialéctica en suspenso. Fragmentos sobre la fistoria, Santiago: ARCIS-LOM.

Bioy Casares, A. (2012) La invención de Morel. Madrid: Alianza Editorial.

Borges, J.L. (2002) Ficciones. Madrid: Alianza Editorial.

. (2003) El Aleph. Madrid: Alianza Editorial.

Bozal, V (2000). Orígenes de la estética moderna, en Historia de las ideas estéticas. Madrid: Balsa dela medusa. Visor.

Burke, E. (2008) Observaciones acerca del sentimiento de lo bello y lo sublime. Madrid: Alianza Editorial.

Calvino, I. (2014) Las ciudades invisibles. Madrid: Ediciones Siruela.

Daumal, R. (1952) El monte análogo. Girona: Editorial Atalanta.

Delgado, M. (1999) Ciudad liquida, ciudad interrumpida. Barcelona: Editorial Anagrama. . (2008) El animal público. Barcelona: Editorial Anagrama.

Elliott, John H. (2006) Imperios del mundo atlántico. España y Gran Bretaña en América, 1492 1830. España: Taurus Historia.

Lanceros, P. (2010) La Huella del crimen. Imagen de la ciudad. Metapolítica: la mirada limpia de la polí tica, ISSN-e 1405-4558, № 68 (Ejemplar dedicado a: El Bicentenario ¿Historia paraqué?).

Maslow, A. (1943) A Theory of human motivation. Psychological Review, 50, 370-396. Recuperado de http://psychclassics.yorku.ca/Maslow/motivation.htm

Swedenborg, E. (2012) El cielo y sus maravillas y el infierno. Buenos Aires: Librería Argentina (UNIYOGA).

Zarone, G. (1993). Metafísica de la ciudad: encanto utópico y desencanto metropolitano. Valencia, España: Editorial Pre-Textos. 